INNOVATION AND THE SOCIAL ECONOMY 
This page intentionally left blank 


\section{Innovation and \\ the Social Economy}

The Québec Experience

EDITED BY MARIE J. BOUCHARD

UNIVERSITY OF TORONTO PRESS

Toronto Buffalo London 
(C) University of Toronto Press 2013

Toronto Buffalo London

www.utppublishing.com

Printed in Canada

ISBN 978-1-4426-4290-4

(6)

Printed on acid-free, $100 \%$ post-consumer recycled paper with vegetablebased inks

\section{Library and Archives Canada Cataloguing in Publication}

Innovation and the social economy : the Quebec experience / edited by Marie J. Bouchard.

Includes bibliographical references.

ISBN 978-1-4426-4290-4

1. Economics - Québec (Province) - Sociological aspects. 2. Social capital (Sociology) - Québec (Province). 3. Cooperative societies - Québec (Province). 4. Non-profit organizations - Québec (Province). 5. Voluntarism Québec (Province). 6. Community development-Québec (Province). 7. Québec (Province) - Social policy. I. Bouchard, Marie J.

HN110.Q8I55 $2013 \quad 306.309714 \quad$ C2012-908473-5

This book has been published with the help of a grant from the Canadian Federation for the Humanities and Social Sciences, through the Aid to Scholarly Publications Program, using funds provided by the Social Sciences and Humanities Research Council of Canada.

University of Toronto Press acknowledges the financial assistance to its publishing program of the Canada Council for the Arts and the Ontario Arts Council.

Canada Council Conseil des Arts for the Arts

du Canada

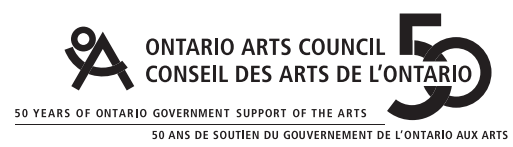

University of Toronto Press acknowledges the financial support of the Government of Canada through the Canada Book Fund for its publishing activities. 